Prepared in cooperation with National Park Service, Whiskeytown National Recreation Area

\title{
Upper Clear Creek Watershed Aquatic Chemistry and Biota Surveys, 2004-5, Whiskeytown National Recreation Area, Shasta County, California
}

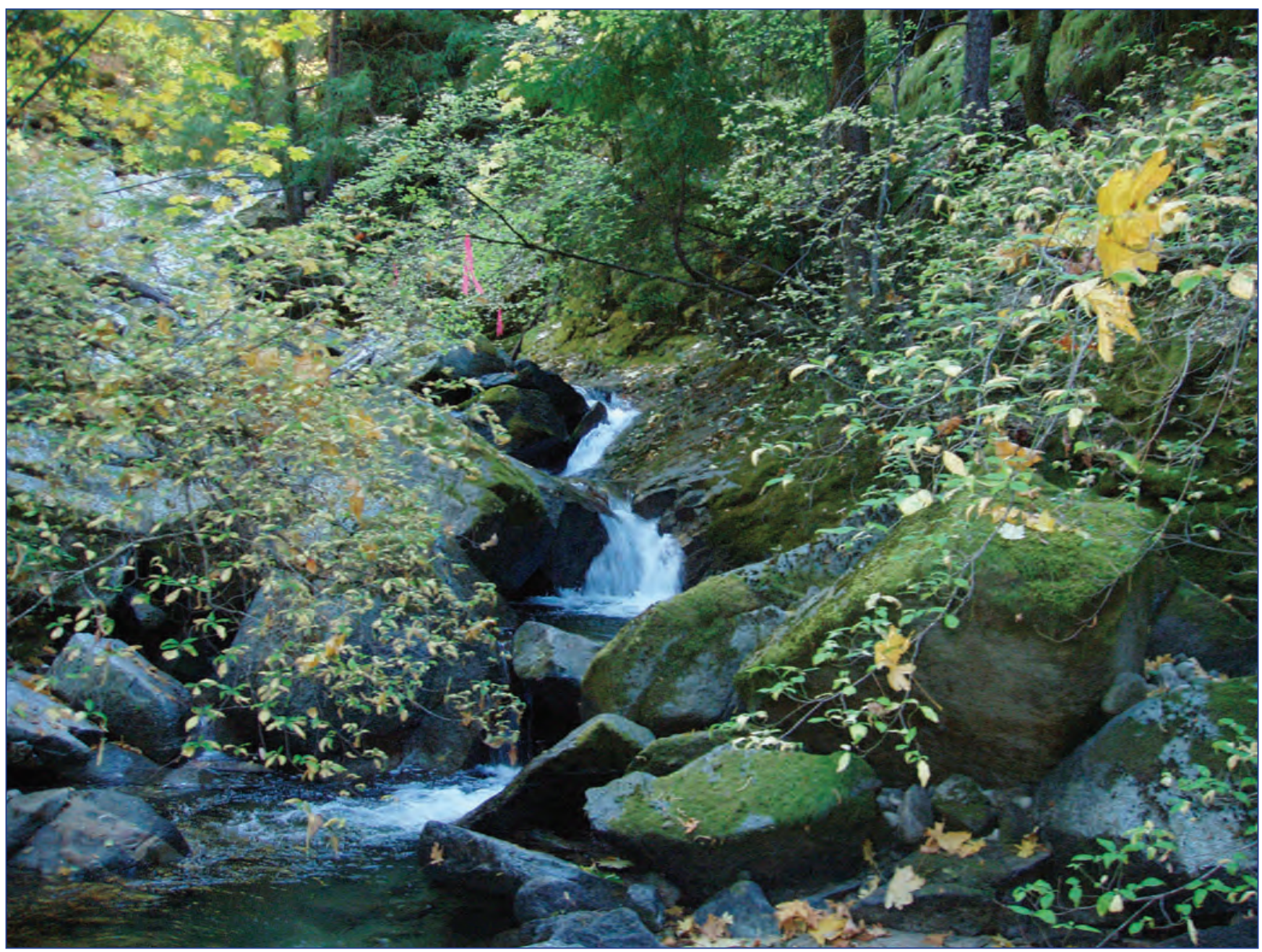

Open-File Report 2012-1173 



\section{Upper Clear Creek Watershed Aquatic Chemistry and Biota Surveys, 2004-5, Whiskeytown National Recreation Area, Shasta County, California}

By Marissa L. Wulff, Jason T. May, and Larry R. Brown

Prepared in cooperation with National Park Service, Whiskeytown National Recreation Area

Open-File Report 2012-1173 


\title{
U.S. Department of the Interior \\ KEN SALAZAR, Secretary \\ U.S. Geological Survey \\ Marcia K. McNutt, Director
}

\author{
U.S. Geological Survey, Reston, Virginia: 2012
}

For more information on the USGS - the Federal source for science about the Earth, its natural and living resources, natural hazards, and the environment, visit http://www.usgs.gov or call 1-888-ASK-USGS.

For an overview of USGS information products, including maps, imagery, and publications, visit http://www.usgs.gov/ pubprod

To order this and other USGS information products, visit http://store.usgs.gov

Any use of trade, product, or firm names is for descriptive purposes only and does not imply endorsement by the U.S. Government.

Although this report is in the public domain, permission must be secured from the individual copyright owners to reproduce any copyrighted materials contained within this report.

Suggested citation:

Wulff, M.L., May, J.T., and Brown, L.R., 2012, Upper Clear Creek watershed aquatic chemistry and biota surveys, 2004-5, Whiskeytown National Recreation Area, Shasta County, California: U.S. Geological Survey Open-File Report 2012-1173, 8 p. 


\section{Contents}

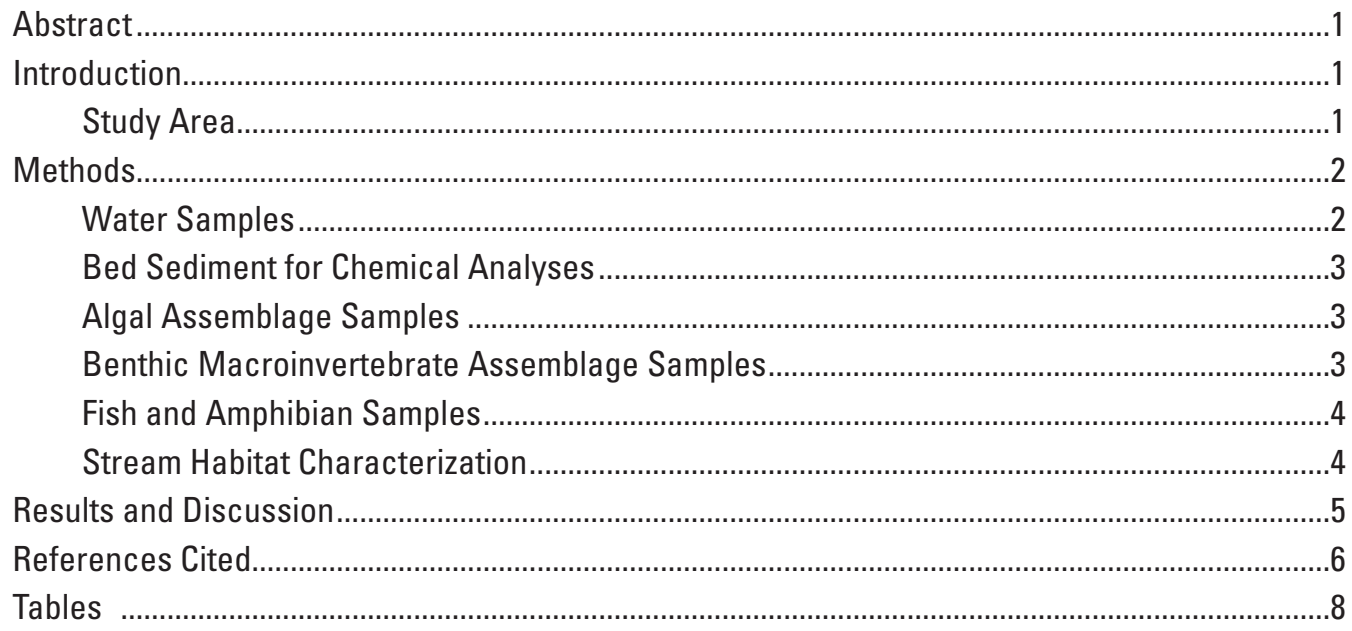

\section{Figures}

1. Map of location of survey sites within Whiskeytown National Recreation Area, Shasta County, California

\section{Tables}

1. Sites sampled during collection of biological inventory for Whiskeytown National Recreation Area, Shasta County, California, 2004-5, including site code, latitude and longitude, official U.S. Geological Survey (USGS) site name, and USGS station ID.....

2. Major ions and water-quality measurements, including $\mathrm{pH}$ and specific conductance, analyzed by the U.S. Geological Survey National Water Quality Laboratory, schedule 1210, for Whiskeytown National Recreation Area, Shasta County, California, 2004-5

3. Major ions and water-quality measurements, including $\mathrm{pH}$ and specific conductance, analyzed by the University of Montana Biogeochemistry Laboratory for water samples from the Whiskeytown National Recreation Area, Shasta County, California, 2005

4. Trace Metals in filtered water analyzed by USGS National Water-Quality Laboratory, schedule 2710, for the Whiskeytown National Recreation Area, Shasta County, California, 2004-5

5. Trace metals in water samples from Whiskeytown National Recreation Area, Shasta County, California, analyzed by the University of Montana 


\section{Tables-Continued}

6. Nutrients in surface-water samples from the Whiskeytown National Recreation Area, Shasta County, California, analyzed by the U.S. Geological Survey National Water-Quality Laboratory, schedule 2711, 2004-5 .

7 Major and trace inorganic elementsin bed-sediment samples from Whiskeytown National Recreation Area, Shasta County, California, analyzed by the University of Montana Environmental Biogeochemistry Laboratory, 2004-5 ....

8. Count of diatom valves by taxa from samples taken at sites in the Whiskeytown National Recreation Area, California, 2004-5. A total of 600 diatom valves (300 diatom frustules or cells) were enumerated and identified at 1000X magnification under a microscope

9. Genera of soft algae, and abundance of live and dead diatoms, for samples? collected from sites in the Whiskeytown Recreation Area, Shasta County, California, 2004-5

10. Average ash-free dry mass, total chlorophyll-a, and total pheophytin for samples collected from the Whiskeytown National Recreation Area, Shasta County, California, 2004 and 2005

11. Taxa list, following the scientific hierarchy of Ode (2003), for macroinvertebrates collected from stream sites in Whiskeytown National Recreation Area, Shasta County, California, 2004-5

12. Selected macroinvertebrate metrics from the Northern California IBI, by Rehn and others (2005), for macroinvertebrate samples collected from stream sites in the Whiskeytown Recreation Area, Shasta County, California, 2004-5

13. Proportional abundance of macroinvertebrates in targeted riffle samples collected from the Whiskeytown National Recreation Area, Shasta County, California, 2004-5

14. Proportional abundance of macroinvertebrates in reach-wide samples collected from the Whiskeytown National Recreation Area, Shasta County, California, 2004-5 8

16. Field measurements for fish and amphibians captured at sites in Whiskeytown National Recreation Area, Shasta Country, California, during fall, 2004 and 2005 ... 8

17. Summary of length and weight data for fish and salamanders captured at sites in Whiskeytown National Recreation Area, Shasta County, California, during fall, 2004 and 2005.

18. Sample-reach lengths, elevations, and selected habitat characteristics for sites sampled in Whiskeytown National Recreation Area, Shasta Country, California, during fall, 2004-5

19. Substrate-size characterization summarized by site for the Whiskeytown National Recreation Area, Shasta Country, California, 2004-5 


\section{Conversion Factors}

SI to Inch/Pound

\begin{tabular}{|c|c|c|}
\hline Multiply & By & To obtain \\
\hline \multicolumn{3}{|c|}{ Length } \\
\hline millimeter (mm) & 0.03937 & inch (in.) \\
\hline meter (m) & 3.281 & foot (ft) \\
\hline \multicolumn{3}{|c|}{ Area } \\
\hline square meter $\left(\mathrm{m}^{2}\right)$ & 0.0002471 & acre \\
\hline \multicolumn{3}{|c|}{ Flow rate } \\
\hline cubic meter per second $\left(\mathrm{m}^{3} / \mathrm{s}\right)$ & 35.31 & cubic foot per second $\left(\mathrm{ft}^{3} / \mathrm{s}\right)$ \\
\hline \multicolumn{3}{|c|}{ Mass } \\
\hline gram (g) & 0.03527 & ounce, avoirdupois (oz) \\
\hline kilogram (kg) & 2.205 & pound avoirdupois (lb) \\
\hline \multicolumn{3}{|c|}{ Volume } \\
\hline mililiter (mL) & 0.03382 & ounce, fluid (fl. oz) \\
\hline mililiter (mL) & 0.002113 & pint (pt) \\
\hline
\end{tabular}

Temperature in degrees Celsius $\left({ }^{\circ} \mathrm{C}\right)$ may be converted to degrees Fahrenheit $\left({ }^{\circ} \mathrm{F}\right)$ as follows:

$$
{ }^{\circ} \mathrm{F}=\left(1.8 \times^{\circ} \mathrm{C}\right)+32
$$

Temperature in degrees Fahrenheit $\left({ }^{\circ} \mathrm{F}\right)$ may be converted to degrees Celsius $\left({ }^{\circ} \mathrm{C}\right)$ as follows:

$$
{ }^{\circ} \mathrm{C}=\left({ }^{\circ} \mathrm{F}-32\right) / 1.8
$$

Specific conductance is given in microsiemens per centimeter at 25 degrees Celsius $(\mu \mathrm{S} / \mathrm{cm}$ at $\left.25^{\circ} \mathrm{C}\right)$.

Concentrations of chemical constituents in water are given either in milligrams per liter (mg/L) or micrograms per liter $(\mu \mathrm{g} / \mathrm{L})$.

Abbreviations

$\begin{array}{ll}\text { CSBP } & \text { California Bioassessment Procedure } \\ \text { DFG-ABL } & \text { California Department of Fish and Game Aquatic Biological Assessment Laboratory } \\ \text { EPA } & \text { Environmental Protection Agency } \\ \text { IBI } & \text { Index of biotic integrity } \\ \text { NPS } & \text { National Park Service } \\ \text { OA/QC } & \text { Quality assurance/ quality control } \\ \text { USGS } & \text { U.S. Geological Survey } \\ \text { WHIS } & \text { Whiskeytown National Recreation Area }\end{array}$


This page intentionally blank 


\title{
Upper Clear Creek Watershed Aquatic Chemistry and Biota Surveys, 2004-5, Whiskeytown National Recreation Area, Shasta County, California
}

\author{
By Marissa L. Wulff, Jason T. May, and Larry R. Brown
}

\begin{abstract}
The U.S. Geological Survey, in cooperation with the National Park Service and Whiskeytown National Recreation Area, performed a comprehensive aquatic biota survey of the upper Clear Creek watershed, Shasta County, California, during 2004-5. Data collected in this study can provide resource managers with information regarding aquatic resources, watershed degradation, and regional biodiversity within Whiskeytown National Recreation Area. Surveys of water chemistry, bed-sediment chemistry, algae assemblages, benthic macroinvertebrate assemblages, aquatic vertebrate assemblages, in-stream habitat characteristics, and sediment heterogeneity were conducted at 17 stream sites during both 2004 and 2005, with an additional 4 sites surveyed in 2005. A total of 67 bed-sediment samples were analyzed for major and trace inorganic element concentrations. Forty-six water samples were analyzed for trace metals and nutrients. A total of 224 taxa of invertebrates were collected during these surveys. Eleven fish species, seven of which were native, and two species of larval amphibians, were collected. A total of 24 genera of soft algae and 159 taxa of diatoms were identified. To date, this survey represents the most comprehensive inventory of aquatic resources within Whiskeytown National Recreation Area, and this information can serve as a baseline for future monitoring efforts and to inform management decisions.
\end{abstract}

\section{Introduction}

The purpose of this report is to document the results of a biotic and abiotic inventory of the assemblages of resident aquatic biota, instream habitat, and water-quality conditions in the streams of the upper Clear Creek watershed, Shasta County, California (fig. 1). The primary objective of the study was to document the aquatic biodiversity supported by the streams in the area so that local resource managers can make informed decisions regarding aquatic resources.

\section{Study Area}

The study area is located in northwestern California in the upper Clear Creek watershed, primarily within the Whiskeytown National Recreation Area (WHIS; fig. 1). The watershed extends across many private and public lands, including National Park Service, Bureau of Land Management, and U.S. Forest Service lands.

Whiskeytown National Recreation Area is located at the convergence of three physiographic provinces: the Cascade Range, the Coast Range, and the Sacramento Valley. The area has a Mediterranean climate characterized by hot, dry summers and cool winters with moderate rainfall. Mean annual rainfall in the area is approximately 1,500 millimeters $(\mathrm{mm})$. The study area lies within the Klamath-Siskiyou ecoregion, which is an area of significant biodiversity, especially for terrestrial plants (DellaSala and others, 1999). In the context of fish zoogeography, it lies within the Central Valley sub-province of the larger Sacramento-San Joaquin Province. The Central Valley fish fauna includes 28 native species, many of them endemic to California, and 40 non-native species (Moyle, 2002). The region's moderately rich herptofauna of 38 species is attributed to the overlap between northern and southern taxa and the presence of appropriate, complex habitat (Bury and Pearl, 1999).

There is a long history of human disturbance in the area. The Clear Creek watershed, historically, was the scene of extensive mining operations and timber harvests, primarily in the mid to late 1800s. Mining activities left numerous dredge tailing piles, pits, tunnels, roads, and acid mine drainage. Runoff from abandoned mine lands has resulted in elevated levels of metals in the stream sediments (Moore, 2002). 


\section{Methods}

Seventeen sites were sampled during the fall (September) of 2004. In fall of 2005, the same 17 sites were sampled, as well as 4 additional sites (table 1; fig. 1). Sampled reaches on the mainstem of Clear Creek were 400 meters (m) long, whereas sampled reaches on the smaller tributary streams were 100-150 m long, depending on channel width. Reach length was roughly 20 times the mean wetted channel width.

\section{Water Samples}

Water samples were collected by using a mid-stream grab method. One replicate sample and one equipment blank were collected during each year of the study period. Equipment blanks were collected according to U.S. Geological Survey's (USGS) protocol as described in Wilde et al. (1999). Blank samples were collected in order to identify potential sources of sample contamination during collection and processing.

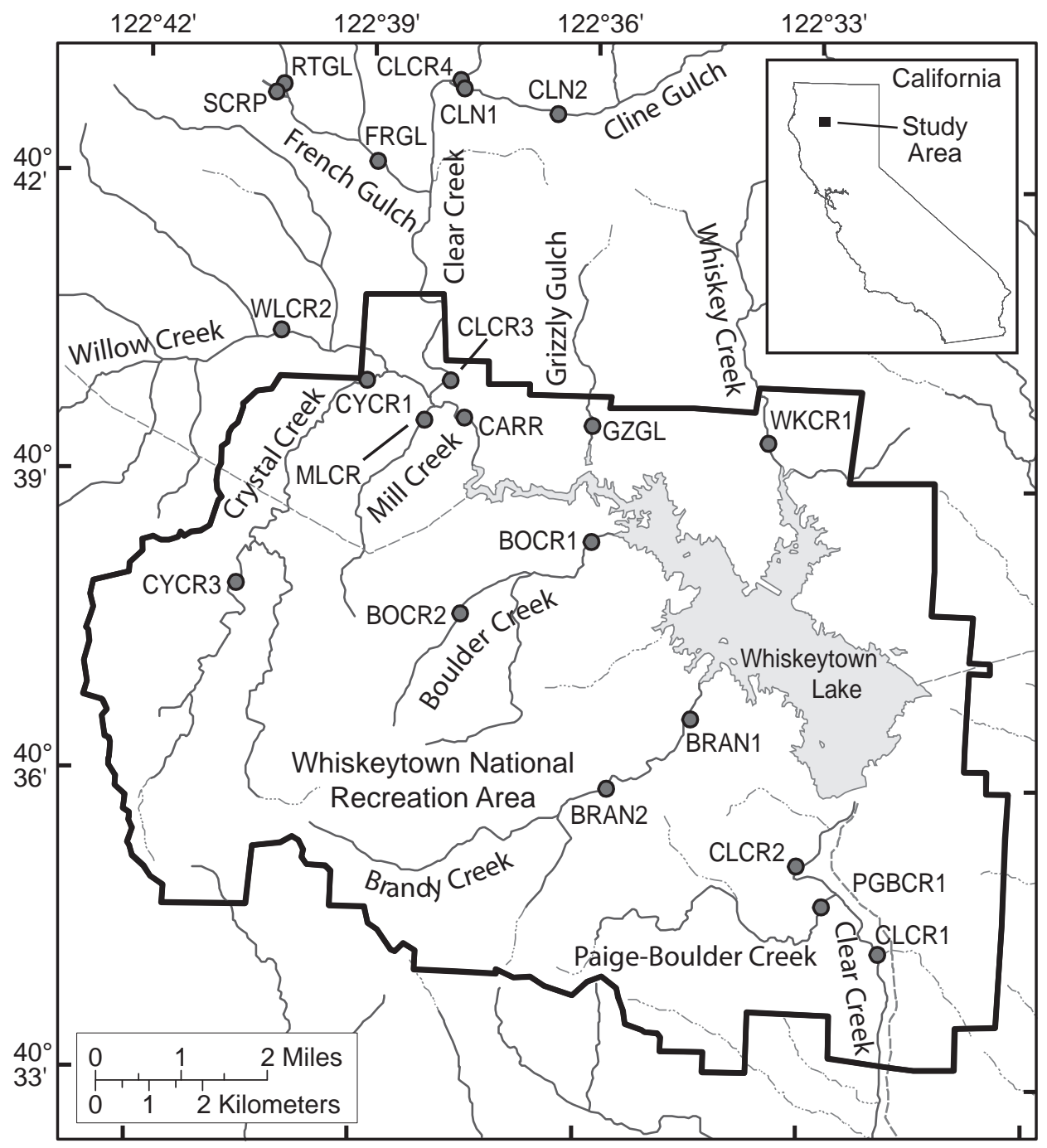

Figure 1. Location of survey sites within Whiskeytown National Recreation Area, Shasta County, California. 
Samples were analyzed for nutrients, major ions, and trace metals at the USGS National Water-Quality Laboratory in Denver, Colorado. Nutrients were determined from 0.45 -micrometer $(\mu \mathrm{m})$ filtered and unfiltered samples by using methods of Patton and Kryskalla (2003) and Fishman (1993). Major ions were determined from filtered water samples by using the methods of Hoffman and others (1996), Garbarino and Struzeski (1998), and Fishman and Friedman (1989). Trace metals were also determined from filtered samples by using the methods of Garbarino and others (2006), Garbarino (1999), and Fishman and Friedman (1989). Selected samples were analyzed for major ions and trace metals at the University of Montana’s Environmental Biogeochemistry Laboratory. Methods of analysis were Environmental Protection Agency (EPA) 300.0 (U.S. Environmental Protection Agency, 1993) and EPA 6020 (U.S. Environmental Protection Agency, 1994), which were similar to those used at the USGS National Water-Quality Laboratory.

\section{Bed Sediment for Chemical Analyses}

Bed-sediment samples were collected for metals analysis by using methods described by Moore (2002). This method uses a partial acid digestion to estimate the biological availability of metals in sediments. Generally, one composite sample was collected per site. At selected sites, composite samples were collected in triplicate to assess the variability of chemical concentrations in bed sediments.

Samples of fine-grain sediments were collected by using a plastic spoon and were sieved with a $63-\mu \mathrm{m}$ mesh nylon-sieve cloth directly into a sample jar. A composite sample consisted of sediment from 5 to 10 locations within the study reach. Samples were placed on dry ice and frozen prior to shipment to the Murdock Environmental Geochemistry Laboratory at the University of Montana for chemical analyses. Sample collection and processing equipment were cleaned between each sampling site by using methods described by Shelton and Capel (1994).

\section{Algal Assemblage Samples}

Algal sampling, including quality assurance and quality control (QA/QC) procedures, was conducted according to standard USGS protocols (Moulton and others, 2002) as applied by Brown and others (2008). At each site, from three to five rocks at each of five locations within the study reach were collected and the benthic algae were removed with a stiff brush. All benthic algae were combined into a single composite sample. Sample areas were measured by cutting an aluminum foil template to the size of each brushed area. The areas of the templates were determined in the laboratory by using a digitizing tablet and then were summed for each site to provide the total area sampled. Triplicate 5-milliter $(\mathrm{mL})$ subsamples were taken from the composite sample for determination of chlorophyll-a concentrations. Triplicate 5-mL subsamples were also taken from the composite sample for determination of ash-free-dry mass. Each 5-mL subsample was filtered onto a $0.47-\mathrm{mm}$ glass fiber filter and then macroinvertebrates, detritus, and large substrate particles were removed with forceps. The filter was then folded into quarters, wrapped in foil, placed in a labeled plastic bag, and frozen on dry ice. Samples were kept frozen in a freezer until analyzed (Wetzel and Likens, 1978). The remaining portion of the composite sample was used for identification and enumeration of algae taxa. Chlorophyll-a analysis, ash-free-dry mass determination, identification, and enumeration of algae were completed at Portland State University, Oregon, under the direction of Dr. Yangdong Pan.

Soft-body algae (live non-diatom algae) were identified and enumerated in a Palmer counting chamber at 400X magnification by using a microscope. A total of 300 algal counting units (live soft-body algae and diatoms) were identified and enumerated. For colonial algae, each colony was counted as one algal unit. For thin filamentous blue-green algae in which cross-walls are often difficult to detect, a $10-\mu \mathrm{m}$ length of trichomes was counted as one algal unit. Counting units were then converted to cell densities.

For diatom analysis, samples were processed with concentrated sulfuric acid and potassium dichromate (Patrick and Reimer, 1966). After numerous rinses with distilled water, cleaned diatom frustules were placed in mounting medium to make permanent slides. A total of 600 diatom valves (300 diatom frustules or cells) were enumerated and identified at $1000 \mathrm{X}$ magnification under a microscope. Diatoms were identified to the species level, whenever possible, by using current taxonomic references. Laboratory processing for all algal samples adhered to QA/QC methods as described in Pan and Stevenson (2001).

\section{Benthic Macroinvertebrate Assemblage Samples}

Benthic macroinvertebrates were collected by using two methods. We collected a targeted riffle sample, or a sample from a relatively shallow and coarse-bedded area over which water flows at a relatively higher velocity and greater turbulence than elsewhere in the stream, by using methods similar to those of the California State Bioassessment Procedure (CSBP) described by Harrington (1996). The standard CSBP includes collection of three replicate kick-net samples (D-frame net with 500-micron mesh) from each of three separate riffles. Also, a reach-wide quantitative multihabitat sample was collected by using methods similar to the U.S. Environmental Protection Agency's Environmental Monitoring and Assessment Program (Peck and others, 2006). Samples were sieved through a $0.5 \mathrm{~mm}$ sieve and then preserved with 95 percent ethanol solution. Both reach-wide and targeted riffle sampling were done during this survey to help the National Park Service (NPS) decide which method would be best for their agency to use for future monitoring. 
The NPS also wanted to build their inventory of species presence as much as possible, which is an area where reach-wide sampling can be very useful.

Samples were analyzed at the California Department of Fish and Game Aquatic Biological Assessment Laboratory (DFG-ABL) during 2004 and at Rhithron Associates, Inc., during 2005. The DFG-ABL adhered to QA/QC procedures detailed in Harrington (2003). Rhithron Associates, Inc., adhered to QA/QC procedures detailed in Rhithron (2002). Organisms were classified to the lowest practical taxon, which was usually genus for well-known groups or some higher taxonomic level for some of the lesser known or difficult to identify taxa. Macroinvertebrates were also summarized as percentage abundance at the genus level or higher taxonomic level for some of the lesser known or difficult to identify taxa. The percentage-abundance format was used because it standardizes counts to a common scale (percentage), provides an easily understood measure of relative abundance for comparison within and between stations, and is a format commonly used for statistical analyses. Invertebrate species were given a tolerance value to pollution based on a 0 to 10 scale, where 0 is the most sensitive to pollution (Ode, 2003).

Invertebrate sample metrics that are part of the northern California index of biotic integrity (IBI) were generated, and IBI scores were calculated for both sample types by methods described in Rehn and others (2005). These IBI scores are intended to give a relative assessment of the stream condition on the basis of a regional indicator.

\section{Fish and Amphibian Samples}

Sampling procedures and QA/QC methods were followed per Walsh and Meador (1998). Fish and larval amphibians were collected with backpack electrofishing by using a Smith-Root Type XII electrofisher. All sites were sampled with at least a single pass of the shocker. Some sites were sampled with three passes, as part of an associated study. Total length in millimeters was measured for fish and larvae of tailed frogs (Ascaphus truei). Snout-vent length was measured (in mm) on Pacific giant salamander larvae (Dicamptodon tenebrosus). Adult amphibians were noted visually but were not collected. A minimum of the first 30 individuals of each species were measured to the nearest 0.1 gram (g) on an electronic balance, with the exception of very small individuals that were sometimes weighed in batches. Length-weight relationships were derived for each site so that weights could be assigned to unweighed individuals. The two Clear Creek sites downstream from the dam (CLCR1, CLCR2) were sampled for fish and amphibians by visual observation while snorkeling. Electrofishing was not done on these sites because of high or deep flows and permitting issues for state and federally listed species. Snorkel observations began at the downstream end of the reach and were completed in a single upstream pass. Fish sampling was conducted in accordance with USGS protocols for sample collection (Moulton and others, 2002) and QA/QC (Walsh and Meador, 1998). Snorkeling is an accepted method in fisheries biology but can underrepresent cryptic species, such as sculpins (Schreck and Moyle, 1990). In this study, a snorkeler near each bank proceeded upstream only counting fish as they moved downstream past the snorkelers. Snorkelers communicated with each other to prevent double counts. Both snorkelers (LRB and JTM) were experienced and familiar with all of the species observed in this study. In addition, LRB is the designated USGS fish taxonomic specialist for California, as outlined in Walsh and Meador (1998). Fish and amphibians were identified to species level and counted. In 2004, fish lengths were estimated visually and recorded. Snorkel surveying in 2005 collected counts of the total number of each species observed.

\section{Stream Habitat Characterization}

In-stream habitat measurements were taken at each site according to the National Water-Quality Assessment Program stream habitat protocol (Fitzpatrick and others, 1998). The stream sampling reach length was set at 20 times the wetted-channel width. Habitat variables were measured for 11 transects separated at equally spaced intervals within each reach. Stream width (wetted channel) was measured directly from a transect tape, and open canopy was measured at midstream with a clinometer. A densiometer was used to calculate canopy cover. Percentage area of habitat features, such as woody debris and overhanging vegetation, were visually estimated within a section of the stream extending 2-m upstream and downstream of the transect tape. Depth, velocity, and substrate were measured at a minimum of three points on each transect. Depth was measured with a wading rod, and velocity with an electronic meter (Marsh-McBirney) at 60 percent of total depth as measured from the bottom. The dominant substrate was classified at each transect point. Habitat variables were computed as the geometric mean of the 11 transect values or the geometric mean of the 33 , or more, point values.

In addition, a more detailed characterization of sediment size classes was conducted at each site. Substrate was clasifyed by size ranging from fine sand $(<2 \mathrm{~mm})$ to large boulder ( $>512 \mathrm{~mm}$ ) and bedrock. A minimum of 20 substrate size measurements were collected for each transect, resulting in approximately 200 individual substrate size measurements for each survey site. The substrate size data were collected to allow assessment of changes in fine sediment resulting from future runoff events. 


\section{Results and Discussion}

Metal and nutrient results for water samples are presented in tables 2 through $\underline{6}$. The highest levels of copper, 10.8 micrograms per liter $(\mu \mathrm{g} / \mathrm{L})$, and zinc, $51.9 \mu \mathrm{g} / \mathrm{L}$, were both found in Willow Creek (WLCR2). Scorpion Creek (SCRP) had the highest level of selenium at $0.98 \mu \mathrm{g} / \mathrm{L}$ and arsenic at $25.9 \mu \mathrm{g} / \mathrm{L}$, whereas Clear Creek (CLCR1) had the highest level of nickel at $2.54 \mu \mathrm{g} / \mathrm{L}$. The range of results across all sites for metals of ecological importance is reported alphabetically as follows: arsenic, 25.9 - less than $0.1 \mu \mathrm{g} / \mathrm{L}$; copper, 10.8 - lass than $0.1 \mu \mathrm{g} / \mathrm{L}$; nickel, 2.54 - less than $0.06 \mu \mathrm{g} / \mathrm{L}$; selenium, 0.98 - less than $0.01 \mu \mathrm{g} / \mathrm{L}$; and zinc, 51.9 - less than $0.6 \mu \mathrm{g} / \mathrm{L}$.

Results for bed-sediment samples are presented in table 7. Of all the sites sampled, Scorpion Creek (SCRP) had the highest concentrations of arsenic,440.2 milligrams per kilogram (mg/kg); mercury, $2.8 \mathrm{mg} / \mathrm{kg}$; and lead, $133.0 \mathrm{mg} / \mathrm{kg}$. Willow Creek (WLCR2) had the highest levels of both copper, 1,190.0 mg/kg, and zinc, 1,224.0 mg/kg. Whiskey Creek (WKCR1) had the highest concentration of cadmium, $11.0 \mathrm{mg} / \mathrm{kg}$, and Clear Creek (CLCR1) had the highest level of nickel, $91.1 \mathrm{mg} / \mathrm{kg}$.

Forty-eight genera of diatoms were identified across all sites during the two sample years (table 8). Also, 10 genera of blue-green algae, 12 genera of green algae, 1 genus of red algae, and 1 genus of yellow-green algae were identified (table 9). The blue-green algae, Anabaena and Oscillatoria, were the most common genera found in the samples across all sites. Brandy Creek (BRAN1) had the greatest number of soft algae, most of which were in the genus Oscillatoria. Clear Creek (CLCR1) and Cline Gulch (CLN2) also had high numbers of algae compared to the rest of the sites. Ash free dry mass, uncorrected chlorophyll-a, corrected chlorophyll-a (concentration of pheophytin subtracted), and total pheophytin for the three subsamples from each site are presented for both years (table 10). Some chlorophyll-a values could not be corrected for the contribution of pheophytin because negative values were obtained for the concentration of pheophytin in some samples. Negative values can be caused by interference from similar compounds in the sample. Although this was not the case for all of the samples, uncorrected chlorophyllvalues should be used when comparing data among sites or between years.

Benthic macroinvertebrate taxa collected at all sites from both years are presented in table 11. Benthic macroinvertebrate metrics that are part of the Northern California IBI (Rehn and others, 2005) and IBI scores are presented in table 12. Metric results of individual samples for major taxonomic groups for both reach wide and targeted riffle samples were averaged for all sites and are presented here as mean $(\mathrm{M})$, standard deviation (SD), and range (R: max-min): Coleoptera taxa (M:5, SD:2, R:11), Diptera taxa (M:20, SD:4, R:19), percentage intolerant (M:23, SD:11, R: 45), percentage non-gastropoda scrapers (M:16, SD:12, R:64), percentage predator taxa (M:14, SD:7, R:32), percentage shredder taxa (M:10, SD:4, R:20), percentage non-insecta taxa (M:14, SD:5, R:24), northern California IBI scores for targeted riffle samples (M:68, SD:11, R:36), northern California IBI scores for reach-wide samples (M:68, SD:11, R:58), and the number of individuals counted per sample (M:542, SD:47, R:242). Sixty-eight percent of Northern California IBI scores for WHIS scored in the 'good' and above range. Willow Creek (WLCR2) had consistently low IBI scores. Boulder Creek (BOCR1), Brandy Creek (BRAN1), Cline Gulch (CLN1), Crystal Creek (CYCR1), Mill Creek (MLCR1), Scorpion Creek (SCRP) and Whiskey Creek (WKCR1) had at least one score in the "very good" range. Eight out of the nine "very good" assessments occurred in 2004. The percentage abundance of macroinvertebrate taxa collected during the fall of 2004 and 2005 are presented for targeted riffle samples and reach-wide samples in tables 13 and $\underline{14}$, respectively.

A total of 11 fish species and 4 species of amphibians were collected during the study (table 15). A summary of all field measurements, including length and weight of each fish and amphibian collected during the study, is presented in table 16. Rainbow trout were found in the most samples, but riffle sculpin was the most abundant species. Larval lampreys were captured but not identified because key adult morphological characteristics are required for species identification. Of the 11 fish taxa, only 4 were non-native species, and of the non-native fish species, only brook trout was found in more than one sample. Brook trout accounted for less than 1 percent of the total number of fish captured. One adult of the non-native bullfrog (Rana catesbeiana) was captured at the Whiskey Creek site, which was also the site where the non-native green sunfish and largemouth bass were collected. Pacific giant salamander larvae were captured at almost every site, except in the mainstem of Clear Creek. Tailed-frog larvae were only observed at the upper sites on Brandy, Boulder, and Crystal Creeks, where riffle sculpin were absent. Adult foothill yellow-legged frogs (Rana boylii) were observed in Cline Gulch, Grizzly Creek, Scorpion Gulch, Mill Creek, Paige-Boulder Creek, and Willow Creek. Total weight and length data for commonly captured (found in five or more sites) fish and amphibians are presented in table 17. Mean and range data for adult tailed frog, tailed frog larvae, bullfrog, foothill yellow-legged frog, green sunfish, hardhead, Kokanee salmon, largemouth bass, and Pacific lamprey were not calculated because they were considered rare in the dataset. 
Habitat characteristics, including reach length, elevation, gradient, discharge, percent riffle, mean wetted width, mean open canopy, mean riparian shade, mean depth, mean water velocity, and dominant substrate, were assessed in both years for each site (table 18). Clear Creek was the largest, lowest gradient river sampled. Headwater portions of Boulder and Crystal Creeks were quite steep (gradient greater than 10 percent). Clear Creek 1 and 2 are both located downstream from the reservoir and are affected by reservoir releases. These sites have some of the largest recorded flows of all the sites. Substrate size and heterogeneity are summarized by site and year in table 19 .

This survey represents the most comprehensive effort to date to document and inventory the status of aquatic resources within upper Clear Creek and WHIS. This information can serve as a baseline for future monitoring efforts and inform future management decisions.

\section{References Cited}

Brown, L.R., May, J.T., and Hunsaker, C.T., 2008, Species composition and habitat associations of benthic algal assemblages in headwater streams of the Sierra Nevada, California: Western North American Naturalist v. 68, p. 194-209.

Bury, R.B., and Pearl, C.A., 1999, Klamath-Siskiyou Herpetofauna: Biogeographic Patterns and Conservation Strategies: Natural Areas Journal, v. 19, p. 341-350.

DellaSala, D.A., Reid, S.B., Frest, T.J., Strittholt, J.R., and Olson, D.M., 1999, A global perspective on the biodiversity of the Klamath-Siskiyou ecoregion: Natural Areas Journal, v.19, p. 300-319.

Fishman, M.J., ed., 1993, Methods of analysis by the U.S. Geological Survey National Water Quality LaboratoryDetermination of inorganic and organic constituents in water and fluvial sediments: U.S. Geological Survey Open-File Report 93-125, 217 p.

Fishman, M.J., and Friedman, L.C., 1989, Methods for determination of inorganic substances in water and fluvial sediments: U.S. Geological Survey Techniques of WaterResources Investigations, book 5, chap. A1, 545 p.

Fitzpatrick, F.A., Waite, I.R., D’Arconte, P.J., Meador, M.R., Maupin, M.A., and Gurtz, M.E., 1998, Revised methods for characterizing stream habitat in the National Water-Quality Assessment Program: Water-Resources Investigations Report 98-4052, 77 p.
Garbarino, J.R., 1999, Methods of analysis by the U.S. Geological Survey National Water Quality LaboratoryDetermination of dissolved arsenic, boron, lithium, selenium, strontium, thallium, and vanadium using inductively coupled plasma-mass spectrometry: U.S. Geological Survey Open-File Report 99-093, 31 p.

Garbarino, J.R., Kanagy, L.K., and Cree, M.E., 2006, Determination of elements in natural-water, biota, sediment and soil samples using collision/reaction cell inductively coupled plasma-mass spectrometry: U.S. Geological Survey Techniques and Methods, book 5, sec. B, chap.1, 88 p.

Garbarino, J.R., and Struzeski, T.M., 1998, Methods of analysis by the U.S. Geological Survey National Water Quality Laboratory- Determination of elements in wholewater digests using inductively coupled plasma- optical emission spectrometry and inductively coupled plasmamass spectrometry: U.S. Geological Survey Open-File Report 98-165, $101 \mathrm{p}$.

Harrington, J.M., 1996, California stream bioassessment procedure: California Department of Fish and Game, Water Pollution Control Laboratory, Rancho Cordova, California, $11 \mathrm{p}$.

Harrington, J.M., 2003, Quality assurance project plan for the California stream bioassessment procedure: California Department of Fish and Game, Water Pollution Control Laboratory, Rancho Cordova, California, 116 p.

Hoffman, G.L., Fishman, M.J., and Garbarino, J.R., 1996, Methods of analysis by the U.S. Geological Survey National Water Quality Laboratory- In-bottle acid digestion of whole-water samples: U.S. Geological Survey Open-File Report 96-225, 28 p.

Meffe, G.K., Nielsen, L.A., Knight, R.L., and Schenborn, D.A., 2002, Ecosystem Management: Adaptive, community based conservation: Island Press, Washington DC, 336 p.

Moore, J.C., 2002, Trace metals in sediments from mineimpacted rivers: Clear Creek, California: Final Contract Report 02WRAG001, University of Montana, 133 p.

Moulton, S.R.II, Kennen, J.G., Goldstein, R.M., and Hambrook, J.A., 2002, Revised protocols for sampling algal, invertebrate, and fish communities as part of National Water-Quality Assessment Program: U.S. Geological Survey, Open File Report 02-150, 87 p.

Moyle, P.B., 2002, Inland Fishes of California: University of California Press, Berkeley, 517 p.

Moyle, P.M., and Moyle, P.R., 1995, Endangered fishes and economics: intergenerational obligations: Environmental Biology of Fishes, v. 43, p. 29-37. 
Ode, P., 2003, List of Californian Macroinvertebrate Taxa and Standard Taxonomic Effort: Aquatic Bioassessment Laboratory, Rancho Cordova, California, 45 p.

Pan, Y., and Stevenson, R.J., 2001, QAPP for Evaluation of Periphyton-Environmental Gradients in Western Streams: Portland State University, Portland, Oregon, 8 p.

Patrick, R., and Reimer, C.W., 1966, The diatoms of the United States: Monograph 13, v. 1, Academy of Natural Sciences of Philadelphia, $688 \mathrm{p}$.

Patton, C.J., Kryskalla, J.R., 2003, Methods of Analysis by the U.S. Geological Survey National Water Quality Laboratory: Evaluation of Alkaline Persulfate Digestion as an Alternative to Kjeldahl Digestion for Determination of Total and Dissolved Nitrogen and Phosphorus in Water, Water-Resources Investigations Report 03-4174, 33p.

Peck, D.V., Herlihy, A.T., Hill, B.H., Hughes, R.M., Kaufmann, P.R., Klemm, D.J., Lazorchak, J.M., McCormick, F.H., Peterson, S.A., Ringold, P.L., Magee, T., and Cappaert, M.R., 2006, Environmental Monitoring and Assessment Program - Surface Waters Western Pilot Study: Field Operations Manual for Wadeable Streams: EPA 620/ R-06/003. U.S. Environmental Protection Agency Office of Research and Development, Washington, D.C, 332 p.

Rehn, A.C., Ode, P.R., and May, J.T., 2005, Development of a Benthic Index of Biotic Integrity (B-IBI) for Wadeable Streams in Northern Coastal California and its Application to Regional 305(b) Assessment. California Surface Water Ambient Monitoring Program, Sacramento, CA, 40 p. Available at http://www.swrcb.ca.gov/water issues/ programs/swamp/reports.shtml)
Rhithron Associates, Inc., 2002, Statement of Qualifications, Missoula, MT, 30 p.

Schreck, C.B., and Moyle, P.B., eds, 1990, Methods for Fish Biology: American Fisheries Society, Bethesda, 704 p.

Shelton, L.R., and Capel, P.D., 1994, Guidelines for Collecting and Processing Samples of Stream Bed Sediment for Analysis of Trace Elements and Organic Contaminants for the National Water-Quality Assessment Program: U.S. Geological Survey Open-File Report 94-458, 20 p.

U.S. Environmental Protection Agency, 1993, Method 300.0: Methods for the Determination of Inorganic Substances in Environmental Samples (EPA/600/R-93/100). http://www. epa.gov/nscep/index.html.

U.S. Environmental Protection Agency, 1994, Method 6020: Inductively Coupled Plasma Mass Spectrometry. http:// www.epa.gov/region8/water/biosolids/analyticalmethods. $\underline{\text { html. }}$

U.S. Geological Survey, 2006, Collection of water samples (ver. 2.0): U.S. Geological Survey Techniques of Water-Resources Investigations, book 9, chap. A4, September 2006, accessed [September 15, 2012], at http:// pubs.water.usgs.gov/twri9A4/.

Walsh, S.J., and Meador, M.R., 1998, Guidelines for quality assurance and quality control of fish taxonomic data collected as part of the National Water Quality Assessment Program: U.S. Geological Survey Water Resources Investigations Report 98-4239, 39 p.

Wetzel, R.G., and Likens, G.E., 1978, Limnological Analyses: W.B. Saunders Company, Philadelphia, 429 p. 


\section{Tables}

These Whiskeytown National Recreation Area (WHIS) Inventory tables are available in a Microsoft ${ }^{\odot}$ workbook for $^{\circ}$ download at http://pubs.usgs.gov/ofr/2012/1173.

Table 1. Sites sampled during collection of biological inventory for Whiskeytown National Recreation Area, Shasta County, California, 2004-5, including site code, latitude and longitude, official U.S. Geological Survey (USGS) site name, and USGS station ID.

Table 2. Major ions and water-quality measurements, including pH and specific conductance, analyzed by the U.S. Geological Survey National Water Quality Laboratory, schedule 1210, for Whiskeytown National Recreation Area, Shasta County, California, 2004-5.

Table 3. Major ions and water-quality measurements, including pH and specific conductance, analyzed by the University of Montana Biogeochemistry Laboratory for water samples from the Whiskeytown National Recreation Area, Shasta County, California, 2005.

Table 4. Trace Metals in filtered water analyzed by USGS National Water-Quality Laboratory, schedule 2710, for the Whiskeytown National Recreation Area, Shasta County, California, 2004-5.

Table 5. Trace metals in water samples from Whiskeytown National Recreation Area, Shasta County, California, analyzed by the University of Montana Biogeochemistry Laboratory, 2005.

Table 6. Nutrients in surface-water samples from the Whiskeytown National Recreation Area, Shasta County, California, analyzed by the U.S. Geological Survey National Water-Quality Laboratory, schedule 2711, 2004-5.

Table 7. Major and trace inorganic elementsin bed-sediment samples from Whiskeytown National Recreation Area, Shasta County, California, analyzed by the University of Montana Environmental Biogeochemistry Laboratory, 2004-5

Table 8. Count of diatom valves by taxa from samples taken at sites in the Whiskeytown National Recreation Area, California, 2004-5. A total of 600 diatom valves (300 diatom frustules or cells) were enumerated and identified at 1000X magnification under a microscope.

Table 9. Genera of soft algae, and abundance of live and dead diatoms, for samples? collected from sites in the Whiskeytown Recreation Area, Shasta County, California, 2004-5.

Table 10. Average ash-free dry mass, total chlorophyll-a, and total pheophytin for samples collected from the Whiskeytown National Recreation Area, Shasta County, California, 2004 and 2005.

Table 11. Taxa list, following the scientific hierarchy of Ode (2003), for macroinvertebrates collected from stream sites in Whiskeytown National Recreation Area, Shasta County, California, 2004-5.

Table 12. Selected macroinvertebrate metrics from the Northern California IBI, by Rehn and others (2005), for macroinvertebrate samples collected from stream sites in the Whiskeytown Recreation Area, Shasta County, California, 2004-5.

Table 13. Proportional abundance of macroinvertebrates in targeted riffle samples collected from the Whiskeytown National Recreation Area, Shasta County, California, 2004-5.

Table 14. Proportional abundance of macroinvertebrates in reach-wide samples collected from the Whiskeytown National Recreation Area, Shasta County, California, 2004-5.

Table 16. Field measurements for fish and amphibians captured at sites in Whiskeytown National Recreation Area, Shasta Country, California, during fall, 2004 and 2005.

Table 17. Summary of length and weight data for fish and salamanders captured at sites in Whiskeytown National Recreation Area, Shasta County, California, during fall, 2004 and 2005.

Table 18. Sample-reach lengths, elevations, and selected habitat characteristics for sites sampled in Whiskeytown National Recreation Area, Shasta Country, California, during fall, 2004-5.

Table 19. Substrate-size characterization summarized by site for the Whiskeytown National Recreation Area, Shasta Country, California, 2004-5. 
Publishing support provided by the U.S. Geological Survey Science Publishing Network, Sacramento and TacomaPublishing Service Centers

For more information concerning the research in this report, contact the Director, California Water Science Center

U.S. Geological Survey

6000 J Street, Placer Hall

Sacramento, California 95819

http://ca.water.usgs.gov 


\section{巟}

